\title{
The Effect of Honey Supplementation on Plasma Levels of Short Chain Fatty Acids in Healthy Infants
}

\author{
MAMDOUH A. MOHAMED, M.D.*; YASMIN G.A. EL GENDY, M.D.*; JIHAN S. HUSSEIN, M.D.** and \\ EMAN M.A. GAML, M.Sc.*
}

The Department of Pediatrics, Faculty of Medicine, A in Shams University* and

The Department of Medical Biochemistry, National Research Center**

\begin{abstract}
Background: Honey is a sweet and flavorful natural product, which is consumed for its high nutritive value and for its positive effects on human health, including antioxidant, antimicrobial, antiinflammatory, woundhealing, antitumor, immunomodulator, prebiotic and probiotic properties. Honey is produced by honey bees from plant nectars, plant secretions and excretions of plant-sucking insects. Concerning its nutrient profile, it represents an interesting source of natural macroand micro-nutrients, consisting of a saturated solution of fructose, glucose, and to Fructo-Oligosaccharides (FOS) that can serve as prebiotics, but also of a wide range of minor constituents, especially phenolic compounds.
\end{abstract}

Aim of Study: Evaluation of the effect of honey supplementation on plasma levels of short chain fatty acids in healthy infants and on the anthropometric measurements.

Subjects and Methods: This study was a single arm prospective interventional study. Twenty healthy infants aged 1 to 2 years were consecutively recruited from the Outpatient Pediatric Clinic of Ain Shams University, Egypt during the period from January, 2020 to February, 2020. Each infant received $2 \mathrm{~g}$ honey/kg/day for 8 weeks. The plasma level of SCFAS and the anthropometric measurements were compared before and after honey intervention.

Results: There was a statistically significant increase in plasma level of SCFAS (formic, acetic and butyric) after honey intervention in the studied group ( $p$-value $<0.05)$. There was also a statistically significant increase in the body weight ( $p$-value 0,001 ) and OFC ( $p$-value 0,031$)$. Honey consumption did not produce any adverse effect in the studied group for 8 weeks.

Conclusion: 8 weeks of honey consumption resulted in increased plasma SCFAS level (formic, acetic and butyric) and increase in the body weight and OFC.

Key Words: Honey - Short chain fatty acids - Occiput frontal circumference.

Correspondence to: Dr. Eman M.A. Gaml, E-Mail: emangaml63@gmail.com

\section{Introduction}

HONEY is a natural substance produced by honey bees. It has both nutritive and health benefits. The positive effects of honey on health are due to its anti-oxidant, anti-microbial, anti-inflammatory and wound healing effects [1].

Honey has to be employed as a dietary adjunct. In this respect, it acts as a prebiotic, which is defined as a non-digestible food ingredient that beneficially affects the host by selectively stimulating the growth and/or activity of a limited number of bacteria (bifid bacteria and lactobacilli) in the intestine [2]

On the account of the nutritional value (303 $\mathrm{kcal} / 100 \mathrm{~g}$ honey) and fast absorption of its carbohydrate, honey is a food suitable for humans of every age [3]. Simply, when orally consumed, its carbohydrates are easily digested and quickly transported into the blood and can be utilized for energy requirements by the human body. The positive effects of honey in infant diet are attributed to effects on the digestion process. One possible cause is the well-established effect of oligosaccharides on $\mathrm{B}$. bifidus [4].

Honey has been used as nutritional and medical product since the earliest times $[\mathbf{5 , 6 ]}$.

Honey contains more than 180 substances, including amino acids, vitamins, minerals and carbohydrate constituents as fructose and glucose in addition to oligosaccharides [7]. Oligosaccharides are provided as fermentable prebiotic substances [8]. To selectively modulate the gut microbial balance in favour of probiotic Lactobacilli and bifid bacteria, thus improving the host metabolic function $[9,10]$. 
Clinical trials try to manipulate the microbiome in the effort to prevent or treat infancy and childhood diseases with a focus on probiotics, prebiotics and symbiotic. Functional foods are foods that affect the component of the gut micro biota, which lead to generation of SCFAs [11].

\section{Aim of the work:}

Evaluation of the effect of honey supplementation on plasma levels of short chain fatty acids and on the anthropometric measurements in healthy infants.

\section{Subjects and Methods}

This study was a single arm prospective interventional study that was conducted on twenty healthy infants aged 1 to 2 years. The sex ratio was $1: 1$. The infants were consecutively recruited from the Outpatient Pediatric Clinic of Ain Shams University, Egypt during the period from January, 2020 to February, 2020.

The study was approved by the Local ethical committee, and an informed consent was obtained from the mother or care giver of each infant before enrolment into the study.

Plasma level of SCFAS were measured and the anthropometric measurements were compared before and after honey intervention including Body Weight (BW) which was measured to the nearest $10 \mathrm{~g}$ by using a standard digital scale, Body Length (BL) which was also measured to the nearest $1 \mathrm{~cm}$, weight for height which more accurately assesses body build and distinguishes wasting (acute malnutrition) from stunting (chronic malnutrition), Body Mass Index which was calculated as the following equation $(\mathrm{BMI}=$ Weight $(\mathrm{kg}) /$ length $(\mathrm{m})^{2}$ ), head circumference (the measurement was approximated to the nearest $0.1 \mathrm{~cm}$ ) and Mid-Upper Arm Circumference (MUAC) which was recorded to the nearest $1 \mathrm{~mm}$.

All anthropometric measures were plotted on WHO, 2006, data were entered on WHO anthropometric software.

Honey intervention: The honey used in this study was a raw, unprocessed clover honey, collected from Al-Mahala-Gharbia Governorate, Egypt, and directly supplied by a beekeeper. Physicochemical analysis of the honey was done in the Chemical Analysis Laboratory of Honey Bee Products, Beekeeping Research Center, Plant Protection Research Institute, Agriculture Research Center, Giza, Egypt. The honey had a pH of 3.7; moisture content of $18.8 \%$; electrical conductivity of 0.27
$\mathrm{mS} / \mathrm{cm}$; and a carbohydrate content of $78.4 \mathrm{~g} / 100 \mathrm{~g}$, with a fructose to glucose ratio of 1.2:0.8, respectively, and a non-reducing sugar content of $3.4 \mathrm{~g} /$ $100 \mathrm{~g}$. The Hydroxymethylfurfuraldehyde (HMF) content was $1.6 \mathrm{mg} / \mathrm{kg}$. Values of HMF less than $15 \mathrm{mg} / \mathrm{kg}$ indicate fresh honey not exposed to heat [12]. Microscopic examination of samples from honey confirmed the presence of pollen grains, which were mainly of clover (Trifolium alexandrinum). The honey was also tested for the presence of Clostridium botulinum spores before use (no spores were detected). Examination of honey for C. botulinum spores was done by centrifugation and filtration of the supernatant, followed by culture on cooked meat [13]. Each participant received honey in an oral dose of $2 \mathrm{~g} / \mathrm{Kg} /$ day for 8 weeks. The calculated dose of honey was dissolved in water in a ratio of 1 to 3 respectively and ingested before breakfast. Dissolving honey in water enhances the antimicrobial effect of honey [14]. The total caloric value of honey was subtracted from the total daily caloric intake. Each participant was provided by 7 glass containers each week. Each container contained the calculated honey dose to be dissolved in water just before ingestion. The care givers instructed not to give their infants any additional honey doses during the study.

Plasma level of short chain fatty acids (Acetic acid, butyric acid and formic acid) were measured before and after honey intervention using HPLC (Agilent technologies 1100 series, with a quaternary pump (G131A model) according to the method described previously by Miwa \& Yamamoto [15] and modified by Hussein et al., [16] and Youness et al., [17].

\section{Statistical analysis:}

Data were collected, revised, coded and entered to the Statistical Package for Social Science (IBM SPSS) version 23 . The quantitative data were presented as mean \pm standard deviation and ranges when their distribution was parametric (normal) while non-normally distributed variables (nonparametric data) were presented as median with Inter-Quartile Range (IQR). Also qualitative variables were presented as number and percentages. The comparison between groups with qualitative data was done by using Chi-square test and Fisher exact test instead of Chi-square test only when the expected count in any cell less than 5 . The comparison between two groups with quantitative data and non-parametric distribution was done by using Mann-Whitney Test. The comparison between two paired groups with quantitative data and parametric distribution was done by using paired $t$-test while 
with non-parametric data the comparison was done by using Wilcoxon Rank test. Spearman correlation coefficients were used to assess the correlation between two quantitative parameters in the same group. The confidence interval was set to $95 \%$ and the margin of error accepted was set to 5\%. So, the $p$-value was considered significant as the following: $p>0.05$ : Non significant. $p<0.05$ : Significant. $p<0.01$ : Highly significant.

\section{Results}

There was a statistically significant increase in plasma level of SCFAS (formic, acetic and butyric) after honey intervention in the studied group ( $p$ value $<0.05$ ) as shown in (Table 1$)$.

There was also a statistically significant increase in the body weight ( $p$-value 0.001$)$ and OFC ( $p$ value 0.031 ) as shown in (Table 2 ).

Table (1): Comparison between serum SCFAS level before and after honey intervention in the studied group.

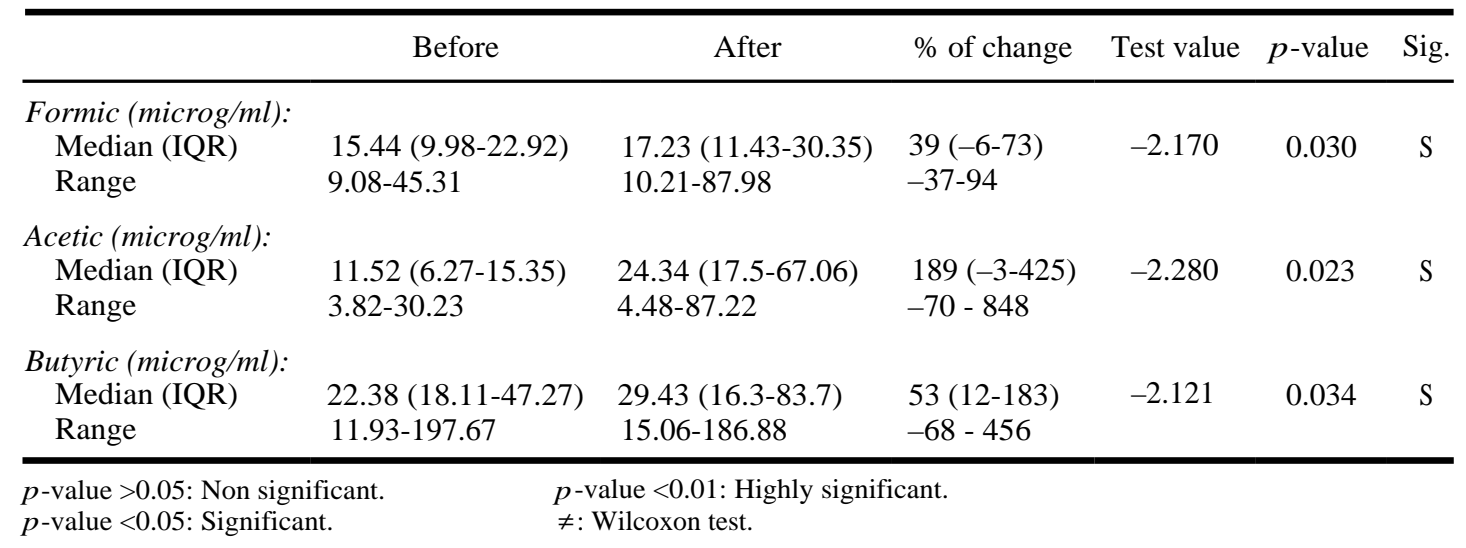

Table (2): Comparison between actual values after honey supplementation and expected values for age of anthropometric measurements.

\begin{tabular}{|c|c|c|c|c|c|}
\hline & $\begin{array}{l}\text { Actual } \\
\text { value }\end{array}$ & $\begin{array}{l}\text { Expected } \\
\text { value }\end{array}$ & $\begin{array}{c}\text { Test } \\
\text { value }\end{array}$ & $\begin{array}{c}p- \\
\text { value }\end{array}$ & Sig. \\
\hline \multicolumn{6}{|c|}{ Wt in $\mathrm{kg}:$} \\
\hline Mean $\pm \mathrm{SD}$ & $10.58 \pm 1.35$ & $10.28 \pm 1.37$ & $3.929 \bullet$ & 0.001 & HS \\
\hline Range & $8.8-13.3$ & $8.3-13$ & & & \\
\hline \multicolumn{6}{|c|}{ Lt in $\mathrm{cm}$ : } \\
\hline Mean $\pm \mathrm{SD}$ & $79.80 \pm 7.44$ & $80.80 \pm 3.20$ & $-0.783 \bullet$ & 0.443 & NS \\
\hline Range & 73-98.5 & $75-86$ & & & \\
\hline \multicolumn{6}{|l|}{ OFC: } \\
\hline Mean $\pm \mathrm{SD}$ & $46.95 \pm 1.99$ & $46.27 \pm 1.09$ & $2.250 \bullet$ & 0.037 & $\mathrm{~S}$ \\
\hline Range & $43-49$ & $44.4-48$ & & & \\
\hline
\end{tabular}

Honey consumption did not produce any adverse effect in the studied group for 8 weeks.

\section{Discussion}

In the present study, 8 weeks consumption in twenty healthy infants resulted in such positive effect as increasing plasma level of SCFAS (formic, acetic and butyric) through providing to gut microbiota otherwise indigestible polysaccharides, oligosaccharides, and proteins to fermentate to SCFAS which can be incorporated in glucose-and lipid synthesis and can function as signaling molecules in several metabolic and endocrine processes [18] and providing also a major source of energy and nutrients [19]

Honey, having $0.75 \%$ of fructo oligosaccharides in its constitution, may act as a prebiotic. Moreover, the detrimental effects of bile salts on Bifidobacterium spp, a ubiquitous inhabitant of the human gastrointestinal tract, can be overcome by the action of fructooligosaccharides and their monomeric derivatives [20].

Honey contains many oligosaccharides and low molecular weight polysaccharides that can resist degradation by host enzymes, and thus remain available as nutrient source for the intestinal micro flora thereby acknowledged as a prebiotic material [21].

When prebiotics enter the lower part of the gastrointestinal tract, they stimulate the growth and/or activity of health-promoting bacteria in the colon. It has been demonstrated that these bacteria generally including lactobacilli and bifidobacteria species protect the host by competing with bacterial and fungal pathogens for availability of nutrients and space and also modulating the immune system [21].

In most of the studies reported, honey has shown to support the growth of the probiotics when incubated in optimum conditions with milk (including reconstituted or fermented) or selective 
growth media. Furthermore, inhibitory action was demonstrated against the pathogens and other intestinal microbes [22-24]

Similar to the positive effect of honey on study of Haddadin [25] to evaluating effect of honey on the growth and metabolism of two Bacterial Species (Bifidobacterium infant is and Lactobacillus acidophilus-both of human intestinal origin) showed that honey beneficially influenced the growth and metabolism [production of Short-Chain Fatty Acids (SCFA)] of these two organisms and it might be reasonable to assume that honey ingested by a consumer would have a similar effect on the native populations of these species in the lower intestine.

To our knowledge, the present study may be the first study correlated between honey supplementation and serum SCFAS levels in healthy infants.

There was also a statistically significant increase in the body weight and OFC as honey supplementation increased GET (gastric emptying time) patients with positive effect on the improvement in the anthropometric measurements and serum albumin [26].

Aly [27] found that Infants who received honey gained more weight than controls, which can be explained by the increased caloric intake in association with honey consumption.

Rao [28] demonstrated increased weight gain in infants receiving prebiotics, whereas Mugambi [29], did not show any benefit of adding prebiotic combinations of Galacto-Oligosaccharides (GOS) and FOS or FOS alone on weight gain. It is known that honey has both pre-and probiotic effects [30]

Evidence of the role of SCFA in appetite regulation has recently appeared in a study using selective modulation of colonic propionate in humans which demonstrated that propionate appears to induce short-term appetite regulation [31].

\section{Conclusion:}

8 weeks of honey consumption resulted in increased plasma SCFAS level (formic, acetic and butyric) and increase in the body weight and OFC.

\section{Acknowledgments:}

We thank very much all children and their parents who agreed to participate in this study. We also thank Dr. Seid J, Professor of Medical Biochemistry at National Research Center who measured plasma level of SCFAS.

\section{References}

1- ALVAREZ-SUAREZ J.M., GIAMPIERI F. and BATTINO M.: Honey as a source of dietary antioxidants: Structures, bioavailability and evidence of protective effects against human chronic diseases. Curr. Med. Chem., 20: 621-38, 2013.

2- SANZ M.L., POLEMIS N., MORALES V., et al.: In vitro investigation into the potentialprebiotic activity of honey oligosaccharides. J. Agric. Food Chem., 53: 2914-21, 2005.

3- BLASA M., CANDRACCI M., ACCORSI A., et al.: Raw millefiori honey is packed full of antioxidants. Food Chem., 97: 217-22, 2006.

4- RIVERO-URGELL M. and SANTAMARIA-ORLEANS A.: Oligosaccharides: Application in infant food (review): Early Hum. Dev., 65: 43-52, 2001.

5- SHAMALA T.R., SHRI J.Y. and SAIBABA P.: Stimulatory effect of honey on multiplication of lactic acid bacteria under in vitro and in vivo conditions. Letters in Applied Microbiology, 30: 453-5, 2000.

6- WALLACE A.: Demonstrating the safety of manuka honey UMF® 20+in a human clinical trial with healthy individuals. British Journal of Nutrition, 103: 1023-8, 2010.

7- CHEN S., CAO Y., FERGUSON L.R., et al.: Flow cytometric assessment of the protectants for enhanced in vitro survival of probiotic lactic acid bacteria through simulated human gastro-intestinal stresses. Applied Microbiology and Biotechnology, 95: 345-56, 2012.

9- KELLOW N.J., COUGHLAN M.T. and REID C.M.: Metabolic benefits of dietary prebiotics in human subjects: A systematic review of randomised controlled trials. British Journal of Nutrition, 111: 1147-61, 2014.

10-RASTALL R.A. and GIBSON G.R.: Recent developments in prebiotics to selectively impact beneficial microbes and promote intestinal health. Current Opinion in Biotechnology, 32: 42-6, 2015.

11- FLINT H.J., SCOTT K.P., LOUIS P., et al.: The role of the gut microbiota in nutrition and health. Nature Reviews Gastroenterology and Hepatology, 9: 577-89, 2012.

12- BOGDANOV S.: Book of Honey. In: Bogdanov S, editor. Honey Composition (Chapter 5): Bee Product Science. September, pp. 10. www.bee-hexagon.net; Accessed October 10.10.14, 2009.

13- KUPLULU O., GANCUOGLA M., OZDEMIR H. and KOLUMAN A.: Incidence of Clostridium botulinum spores in honey in Turkey. Food Control, 17: 222-4, 2006.

14- MOLAN P.C.: Honey as an antimicrobial agent"In: Mizrahi, A. and Lensky, Y. (eds.) Bee Products: Properties, Applications and Apitherapy. Plenum Press, New York, pp. 27-37, 1997.

15-MIWA H. and YAMAMOTO M.: High-performance liquid chromatographic analysis of serum short-chain fatty acids by direct derivatization. Journal of chromatography, 421: 33-41, 1987.

16- HUSSEIN J.S., EL-KHAYAT Z., MORSY S., et al.: The effect of fish oil on oxidant/antioxidant status in diabetic rats through the reduction of arachidonic acid in the cell membrane. Int. J. Pharm. Pharm. Sci., 6 (2): 196-9, 2014. 
17- YOUNESS E.R., HUSSEIN J.S., IBRAHIM A.M., et al.: Flaxseed Oil Attenuates Monosodium Glutamate-Induced Brain Injury via Improvement of Fatty Acids Contents. Biomedical \& Pharmacology Journal, Vol. 12 (2): $527-$ 32, 2019.

18- CANFORA E.E., JOCKEN J.W. and BLAAK E.E.: Shortchain fatty acids in control of body weight and insulin sensitivity. Nat. Rev. Endocrinol., 11 (10): 577-91, 2015.

19- GIBSON G.R., PROBERT H.M., VAN LOO J., et al.: Dietary modulation of the human colonic microbiota: Updating the concept of prebiotics. Nutrition Research Reviews, 17: 259-75, 2004.

20- MIGUEL M.G., ANTUNES M.D. and FALEIRO M.L.: "Honey as a Complementary Medicine". Integrative Medicine Insights, Volume 12: 1-15, 2017.

21- LANDRY B.K.U., MOUMITA S., JAYABALAN R. and FRANÇOIS Z.N.: "Probiotics and Prebiotics: Review Research Journal of Pharmaceutical, Biological and Chemical Sciences, ISSN: 0975-8585, 2016.

22- SHIN H. and USTUNOL Z.: Carbohydrate composition of honey from different floral sources and their influence on growth of selected intestinal bacteria: An in vitro comparison. Food Research International, 38: 721-8, 2005.

23- LUCAN M., et al.: Inhibitory effect of honey-sweetened goat and cow microencapsulated Bifidobacterium: Effect of honey addition. Journal of Microencapsulation, 32: 329-35, 2009.

24- SARAN S., SINGH K., BISHT M.S., et al.: Comparison of prebiotics for the functional attributes of an indigenous isolate of Lactobacillus acidophilus. International Journal of Probiotics and Prebiotics, 6: 173-8, 2011.

25- HADDADIN M.S.Y., NAZER I., SARA' JAMAL A.R., et al.: Department of Food Technology and Nutrition, Pakistan Journal of Nutrition, 6 (6): 693-7, 2007.

26- SHAABAN S.Y., ABDULRHMAN M.A., NASSAR M.F. and FATHY R.A.: Effect of honey on gastric emptying of infants with protein energy malnutrition Eur. J. Clin. Invest., 40 (5): 383-7, 2010.

27- ALY H., SAID R.N., WALI I.E., et al.: Medically Graded Honey Supplementation Formula to Preterm Infants as a Prebiotic: A Randomized Controlled Trial. J. Pediatr. Gastroenterol. Nutr., 64 (6): 966-70, 2017.

28- RAO S., SRINIVASJOISN R. and PATOLE S.: Prebiotic supplementation in full-term neonates: A systematic review of randomized controlled trials. Arch. Pediatr. Adolesc. Med., 163: 755-64, 2009.

29- MUGAMBI M.N., MUSEKIWA A. and LOMBARD M.: Probiotics, prebiotics infant formula use in preterm or low birth weight infants: A systematic review. Nutr. J., 11: $1,2012$.

30- MOHAN A., QUEK S.Y., GUTIERREZ-MADDOX G., et al.: "Effect of honey in improving the gut microbial Balance Food Quality and Safety", 1 (2): 107-15, 2017.

31- CHAMBERS E. S., VIARDOT A., PSICHAS A., et al.: Effects of targeted delivery of propionate to the human colon on appetite regulation, body weight maintenance and adiposity in overweight adults. Gut., 64 (11): $1744-$ 54, 2015. 


\section{تآثير إعطاء عسل النحل على مستوى الآحماض الدهنية قصيرة السلسلة فى بلازما الآطفال الرضع الآصحاء الاء التهي}

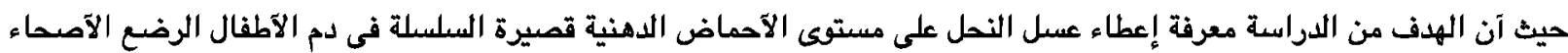
وعلي قياسات الآطفال الجسمانية المختلفة.

وهذه الدراسة عبارة عن دراسة مستقبلية تداخلية حيث جرات على •r طفل من الآصحاء يتراوح آعمارهم من سنة إلى سنتين ومن كلا

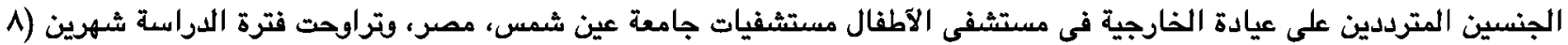
آسابيع). وتم الحصول على الموافقة من آحد الوالدين على الآقل قبل عمر الدراسة على على الآطقال. وتم خضوع جميع الآطفال إلى ما يلى:

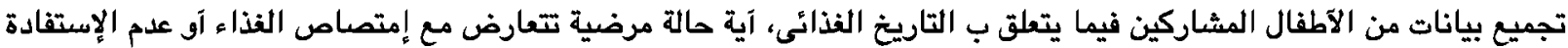

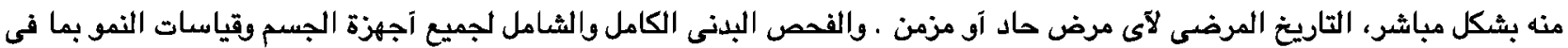

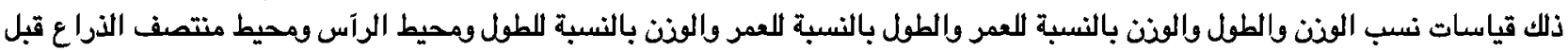

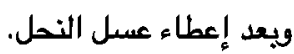

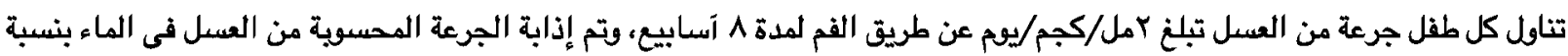

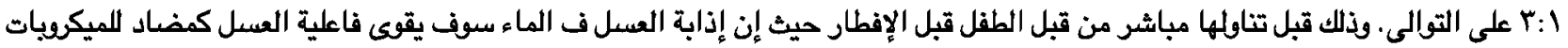

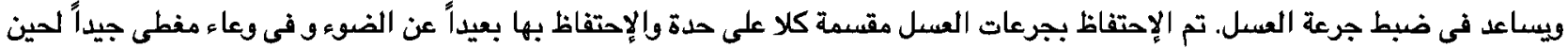

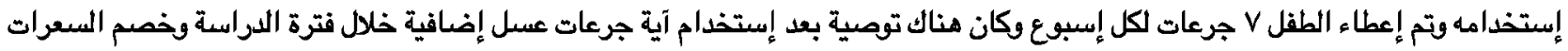

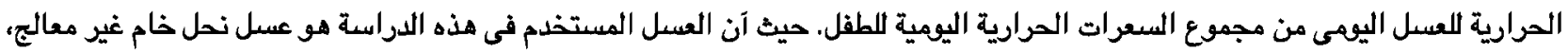
يتم جمعه من المحلة قبل الإستخدام Clostridium botulinum بمحافظة الغربية، مصر، تم توفيره مباشرة من قبل مربى النحل وتم إختباره بحثاً عن جراثيم.

في هذه الدراسة فيما يتعلق بالقياسات الآتثربومترية، بعد مرود شهرين على تتاول العسل كمكمل غذائى، آظهرت النتائج وجود زيادة ذات

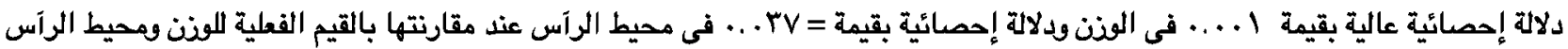

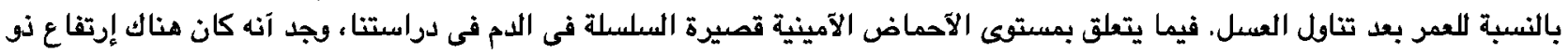

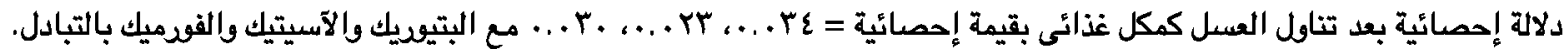

